\title{
PsZichológIAI ÉLETMINŐSÉG-VIZSGÁLAT KÉT VÁROS TÜKRÉBEN
}

\author{
Botházi Renáta, Balázs Előd, DéGi László Csaba
}

\begin{abstract}
Study of psychological wellbeing from two urban perspectives. Our study focuses on dimensions of psychological quality of life, in the mirror of demographic and psycho-social variables, based on a survey research. The survey took place in Nyíregyháza and Gyergyószentmiklós. Our goal was to study if there is significant association / correlation between: place of residence, age, gender, highest educational level, marital status, cardiac status and individual autonomy, sense of dominion over the environment, personal development, positive relationships maintained with others, purpose in life and self-acceptance. Our research findings suggested that the responder's sense of autonomy, both from Nyíregyháza and Gyergyószentmiklós, is not significantly associated with the five demographic variables or psychosocial variable cardiac status. However the sense of dominion over the environment, personal growth, purpose in life, positive relations with others and self-acceptance are significantly associated with educational level, and purpose of life with place of residence as well.
\end{abstract}

Keywords: health, psychological wellbeing, demographic and psychosocial variables DOI: $10.19055 / \mathrm{ams} .2013 .4 / 10 / 9$

\section{BEVEZETő}

Az életminőség fokozása a modern társadalmak célkitüzései közé tartozik, viszont az a felfogás megdőlt, mi szerint a tudományos, gazdasági fejlődés fokozódó jólétet fog eredményezni, és ezáltal a jóllét jelentős javulásával fog együtt járni (Kopp, 2006).

Az életminőség egy igen komplex, alapvetően szociológiai fogalom, viszont más szempontok érvényesülnek, ha az egyén vagy éppen a társadalom szintjén kívánjuk meghatározni azt. Az életminőség-vizsgálatok iránti érdeklődés az utóbbi években öltött testet, mely hátterében az egyik legfontosabb tényezőnek az egészségügyi tevékenységben megjelenő krónikus betegségek tekinthetőek. A vizsgálatok alapja és kiindulópontja pedig az egészség, illetve hogy hogyan is mérhető az. Az egészség fogalma kezdetben egyenlő volt a betegség hiányával, egészen az Egészségügyi Világszervezet (WHO) 1948-as (idézi Tringer, 2005) új és korszerü, pozitív terminusokkal ellátott 
egészség meghatározásig: ,a teljes testi, lelki és társadalmi jóllét és nem egyszerüen a betegségek vagy fogyatékosságok hiánya". A definíció értelmében az egészségnek nem csak biológiai, hanem pszichológiai és szociális összetevöit is szem elött kell tartanunk. Ezt egészítette ki a híres 1948-as Ottawai Nyilatkozat (idézi Tringer, 2005), amely az egészség fogalmát további pozitív jegyekkel illette: „Az egészség olyan állapot, melyet az anatómiai integritás, a teljesitményre való képesség, a személyes értékek, a családi, munka- és közösségi szerep, a fizikai, biológiai és társadalmi stresszel való megküzdés képessége, a jóllét érzése, a betegség és a korai halál rizikóitól való mentesség jellemez”. A túlzottan orvosi és betegségasszociációkat keltő „egészség” helyett a ,jóllét” (,wellness”), valamint az életminőség kategóriája került reflektorfénybe. Végeredményben elmondhatjuk, hogy az egészségdefiníció az elmúlt években olyan változásokon ment keresztül, amelyek eredményeképpen a negatív indikátorok helyett a pozitív attribútumok kerültek előtérbe (Tringer, 2005). Így tehát megállapíthatjuk, hogy életminőség egy olyan multifaktoriális fogalom, amely magába foglalja a szomatikus állapotot és működőképességet, pszichés állapotot és lelki-szellemi jólétet, a szociális müködést a szakmai, társas és családi szférában egyaránt (Stauder és Novák, 2001).

A népesség jóllétét kedvezőbbé és fokozni kívánó életminőség vizsgálatra szolgáló modellek három nagyobb tudományterülethez kötődnek: a szociológiához, a pszichológiához és az egészségtudományhoz.

Jelen tanulmány egy pszichológiai megközelítésü életminőség kérdőív segítségével végzett kutatás alapján készült el, amely Carol Ryff (1989) nevéhez füződik. Az életminőség pszichológiai megközelítésủ vizsgálódásának háttere az ún. pozitív pszichológiai irányzat, melynek megalapozói és jeles képviselői Martin Seligman, Csíkszentmihályi Mihály és Ed Diener. A pozitív pszichológiai irányzat meglehetősen épít Arisztotelész boldogság definíciójára, miszerint az életminőség a boldogsággal azonosítható. Seligman (idézi Kopp, 2006) ennek értelmében a boldogság három lépcsőjét különbözteti meg, melyek közül az első az öröm, az élvezet, vagyis a hedonisztikus boldogságkeresés szintje. És habár ennek a szintnek is megvan a saját funkciója, hiszen az örömnek, a vidámságnak igen jelentős szerepe van az pozitív életminőség kialakulásában, viszont ez a lelkiállapot még nem azonos a boldogsággal és jólléttel, még ha a modern társadalom embere ebben is látja. A boldogság második szintje a bevonódás és elkötelezettség, melynek során az ember teljesen feloldódik egy tevékenységben, és egy magasabb szintủ élményt él át. Ezt az élményt nevezi Csíkszentmihályi Mihály „flow” élménynek, melyet magyarra fordítva ,áramlatnak" nevezünk. A harmadik szint a boldogságot az értelmes élet, az élet értelmében látja. Ez felel meg tulajdonképpen az arisztotelészi „eudemonia” fogalomnak, ami nem élményt, nem is állapot, hanem aktivitást jelent. A boldogságnak ezt a fajta legmagasabb, harmadik lépcsőfokát az ember önmagával való harmóniája, az életcélok, a személyes növekedés, a másokkal való pozitív kapcsolatok és az autonómia jellemzik (Kopp, 2006). Az élet értelmével jellemezhető boldogság nemtől, életkortól és szociális helyzettől függetlenül jobb egészségi mutatókkal jár együtt, mint a hedonista boldogság élmény (idézi Kopp, 2006 - Ryff és mtsai, 2004). Tanulmányunk ezt a harmadik lépcsőt vizsgálja tüzetesebben. 


\section{NÉHÁNY SZÓ A MINTÁRÓL}

Kutatásunk helyszínéül egy magyarországi és egy romániai várost választottunk, Nyíregyházát, illetve Gyergyószentmiklóst. Nyíregyháza Szabolcs-Szatmár-Bereg megye székhelye, amely a maga 119746 fös lakosságával Magyarország hetedik legnagyobb városának számít. A nyíregyházi lakosság 46,36\%-a férfi, 56,64\%-a pedig nő. Nemzetiség szerinti megoszlást tekintve a nyíregyháziak közül 103126-an vallották magukat magyarnak a 2011-es népszámláláson, 4161-en pedig más nemzetiségünek (cigány, német, ukrán, szlovák) (KSH, 2011). Gyergyószentmiklós szintén egy többségében magyarlakta város, Romániában, Hargita megyében található. A megye harmadik legnépesebb városa, a stabil lakosság 2011-ben 17705 fö volt, melyből 48,63\% férfi és $51,37 \%$ pedig nő (INSSE, 2011).

Pszichológiai életminőség-vizsgálatunkat kérdőíves felmérés keretében készítettük el, Gyergyószentmiklóson 202 sikeres kérdőívet, míg Nyíregyházán 107 kérdőívet, összesen 309-t sikerült lekérdeznünk. A megkérdezett gyergyószentmiklósiak átlagéletkora 40 köré tehető, nemek közti megoszlását tekintve $41 \%$-uk férfi és $59 \%$-uk nő, míg a nyíregyháziak átlagéletkora egy kicsivel magasabb, 46 év volt, nemi megoszlás tekintetében $35,2 \%$-uk nő és $64,8 \%$-uk férfi.

A gyergyószentmiklósi minta a gyergyószentmiklósi össznépesség 1,02%-át teszi ki, a nyíregyházi minta pedig a nyíregyházi lakosság 0,08 \%-át reprezentálja. A gyergyószentmiklósi minta kiválasztásánál első lépésben az alábbi csoportokra osztottuk fel a 18-60 közötti korcsoportot: 18-30 év, 30- 40 év, 40-50 év, 50-60 év. A csoportosítást azért tartottuk szükségesnek, hogy mindegyik csoportban egységesen 50 személy vegyen részt, ezáltal mindegyik korcsoport egyenlő arányban szerepel a mintánkban. A kutatásban résztvevő gyergyószentmiklósi minta átlagéletkora így 40,8 év. A kérdőívek kitöltésére több helyszínen került sor: egy ifjúsági szervezetnél, egy varrodában, tanügyi intézményben és egy egészségügyi intézményben. A helyszínek kiválasztásakor az intézmények/szervezet vezetőjével előzetesen megvizsgáltuk a munkavállalók/ klienscsoport összetételét, kor, nem iskolai végzettség szerint, a minta heterogenitására törekedve. A kérdőívek kitöltésére egy hét állt a válaszadók rendelkezésére, amelyet személyesen vettünk át a határidő lejárta után, lehetőséget adva a válaszadóknak a számukra nem érthető részek megbeszélésére.

\section{A KÉRDöívRőL}

A kérdőívben a hat életminőségi dimenzió mindegyikéhez társult egy kérdésblokk, amely bekerült a kérdőívbe. Az adott kérdésre érkező válaszok mindegyikéhez társult egy pontszám, 1-től 6-ig. Egy dimenzióhoz tizennégy kérdés társult, így a maximális pontszám 84 .

Az autonómia dimenziójánál magas pontszám esetén a személy saját standardjai alapján értékeli önmagát, társadalmi nyomás alatt is képes önálló maradni. Alacsony 
pontszám esetén a személyt külső elvárások, mások értékelései irányítják, képtelen fontos döntések meghozatalára mások segítsége nélkül.

A környezethez való alkalmazkodás dimenziójánál magas pontszám esetén a személy jól alkalmazkodik környezetéhez, hatékonyan kihasználja a környezete nyújtotta lehetöségeket. Alacsony pontszám esetén az egyén nehezen kezeli mindennapi gondjait, úgy érzi képtelen javítani a környezetén, nem ismeri fel az adódó lehetőségeket.

A személyes fejlődés dimenziójánál az egyén hisz az állandó fejlődésben, nyitott az újra, képes megvalósítani önmagát, állandóan gyarapítja tudását. Alacsony pontszám esetén az egyén fejlődése stagnál, unott az élet minden területén, nem képes új viselkedési modell alkalmazására.

A másokkal fenntartott pozitív kapcsolatok dimenziójában azok a személyek rendelkeznek magas pontszámmal, akik társas kapcsolataiban empatikusan, őszintén, érdeklődően és megértően tudnak viszonyulni másokhoz. Ezen személyek ellenkezője kevés emberrel tart fenn őszinte baráti kapcsolatot, frusztrált és zárkózott személyiség.

Életcélok dimenziója: Magas pontszám esetén a személynek határozott céljai vannak, hisz a jelen és múltbeli életének értelmében, és abban, hogy céljai megvalósulnak a jövőben. Alacsony pontszám esetén a személy nem tervez, mert nem látja az irányt, nem érdekli a jövő.

Az önelfogadás dimenziójánál magas pontszám esetén a személynek pozitív az önképe, elfogadja önmagát jó és rossz tulajdonságaival együtt. Alacsony pontszám esetén a személy elégedetlen önmagával, megvalósításaival, más szeretne lenni (Ryff, 1989).

\section{AZ ADATOK ELEMZÉSE}

Statisztikai elemzésünk hat nagyobb lépést foglal magába. Az első öt lépésben öt különböző statisztikai változót vetettünk össze az életminőség hat dimenziójával. Így tehát megvizsgálásra került, hogy miként fest az egyének autonómia-érzete, környezet fölötti uralma, személyiségfejlődése, másokkal ápolt pozitív kapcsolatai, életcélja, illetve önelfogadása annak tükrében, hogy hol élnek, hány évesek, mi a legmagasabb iskolai végzettségük, mi a családi állapotuk és melyik nemhez tartoznak. Az utolsó lépésként az életminőség és a kardiológia állapot közötti összefüggést vizsgáltuk, ahol a korábbiakhoz hasonlóan érdekes eredményekre jutottunk. A legtöbb dimenziónak két táblázatot készítettünk. Enne fö oka, hogy az adatokat átláthatóbbá és könnyebben érthetővé, az elemzést pedig követhetőbbé tegyük az olvasó számára.

\section{A TELEPÜLÉS-VÁLTOZÓ ÉS AZ ÉLETMINŐSÉG KAPCSOLATA}

Az elemzés szempontjából relevánsnak ítélt változók közül elsőként az adatfelvétel helyszínével foglalkozunk. Mivel a lekérdezés két városban, Gyergyószentmiklóson és Nyíregyházán történt, adta magát a felvetés, kimutatható-e szignifikáns különbség a különböző lakhelyen élők életminőségi mutatói között.

Az autonómia-dimenzió kérdésblokkjára összesen 288 válasz érkezett, ebből 187 
Gyergyószentmiklósról, 101 Nyíregyházáról. A 84-es skálán (lásd: a kérdőívről) mindkét város lakói jobb értékeket értek el a közepesnél, és lényeges eltérés nem mutatko zik a gyergyószentmiklósi, illetve nyíregyházi átlag-együtthatók között. Ennek megfelelően a szignifikancia vizsgálat is azt mutatta ki, hogy nincs különbség az egyének autonómia-érzete között, abból eredően, hogy más-más városban élnek.

1. táblázat. A helyszín-változó kapcsolata az életminőség dimenzióival (1. rész)

\begin{tabular}{|c|l|c|c|c|c|}
\hline $\begin{array}{c}\text { Életminőség- } \\
\text { dimenzió }\end{array}$ & \multicolumn{1}{|c|}{ Helyszín } & $\begin{array}{c}\text { Átlagérték } \\
\text { a 84-es skálán }\end{array}$ & $\begin{array}{c}\text { Átlagos } \\
\text { eltérés }\end{array}$ & F-érték & p-érték \\
\hline \multirow{2}{*}{ Autonómia } & Gyergyószentmiklós & 58,08 & 9,58 & 0,24 & 0,62 \\
\cline { 2 - 6 } & Nyíregyháza & 57,07 & 9,58 & & \\
\hline \multirow{2}{*}{$\begin{array}{c}\text { Környezet } \\
\text { uralása }\end{array}$} & Gyergyószentmiklós & 59,26 & 10,14 & 0,08 & 0,76 \\
\cline { 2 - 6 } & Nyíregyháza & 57,16 & 12,09 & & \\
\hline \multirow{2}{*}{$\begin{array}{c}\text { Személyes } \\
\text { fejlödés }\end{array}$} & Gyergyószentmiklós & 59,96 & 10,72 & 0,15 & 0,69 \\
\cline { 2 - 6 } & Nyíregyháza & 56,96 & 10,7 & & \\
\hline
\end{tabular}

Az autonómia-dimenzió kérdésblokkjára összesen 288 válasz érkezett, ebből 187 Gyergyószentmiklósról, 101 Nyíregyházáról. Ahogy azt az 1. táblázat is mutatja, a közepesnél magasabb értékeket értek el mindkét város lakói az autonómia-skálán. Az átlagtól való eltérés átlaga éppen egyforma értéket mutat mindkét esetben: 9,58-at. Ez az érték normálisnak mondható, azaz nem túl nagy a 84-es skálán.

Az autonómiánál maradva, látható, hogy a p-érték jóval meghaladja a 0,05-öt, az F-érték pedig ennek megfelelően kicsi. Elmondható tehát, hogy az egyének lakóhelye nem befolyásolja szignifikánsan az autonómia érzetüket.

Szinte a fentiekkel azonos mutatókat kaptuk a lakóhely kapcsán a környezet egyéni uralása és a személyes fejlödés-dimenziók esetében is. Az átlagértékek továbbra is $\mathbf{5 6}$ és 60 között alakultak a fentebb említett skálán, az átlagos eltérés értéke továbbra sem utal nagyfokú szóródásra, míg a 0,76-os (környezet uralása) és 0,69-es (személyiségfejlődés) p-érték ezen esetekben is azt igazolja, hogy a helyszín-változó nem hat ki szignifikánsan ezekre az életminőségi dimenziókra.

A 2. táblázatban a többi három életminőségi dimenziót vetettük össze a lakhellyel. A másokkal való pozitív kapcsolatok tekintetében kiderült, hogy alig van különbség a gyergyói és a nyíregyházi megkérdezettek válaszai között. Az átlagos eltérés is majdnem megegyezik a két településen. Így van ez az önelfogadás esetében is, ahol az átlagértékek szinte megegyeznek, mind a két település eredményei között, mind a korábbi dimenziókhoz képest. 
2. táblázat. A helyszín-változó kapcsolata az életminőség dimenzióival (2. rész)

\begin{tabular}{|c|l|c|c|c|c|}
\hline $\begin{array}{c}\text { Életminőség- } \\
\text { dimenzió }\end{array}$ & \multicolumn{1}{|c|}{ Helyszín } & $\begin{array}{c}\text { Átlagérték } \\
\text { a 84-es skálán }\end{array}$ & $\begin{array}{c}\text { Átlagos } \\
\text { eltérés }\end{array}$ & F-érték & p-érték \\
\hline $\begin{array}{c}\text { Pozitív kapcso- } \\
\text { latok másokkal }\end{array}$ & Gyergyószentmiklós & 60,29 & 9,82 & 1,52 & 0,21 \\
\cline { 2 - 7 } & Nyíregyháza & 59,11 & 10,86 & & \\
\hline \multirow{2}{*}{ Életcél } & Gyergyószentmiklós & 58,92 & 8,93 & 3,76 & 0,05 \\
\cline { 2 - 7 } & Nyíregyháza & 53,8 & 9,81 & & \\
\hline \multirow{2}{*}{ Önelfogadás } & Gyergyószentmiklós & 58,71 & 10,6 & 1,88 & 0,17 \\
\cline { 2 - 7 } & Nyíregyháza & 56,93 & 11,85 & & \\
\hline
\end{tabular}

Akadt azonban egy olyan életminőség-mutató is, amely szoros összefüggést mutat az egyének lakóhelyével. Ez nem más, mint az életcél. Már az átlagértékek közötti különbségböl is sejthető (58,92-Gyergyószentmiklós, 53,8-Nyíregyháza), majd a 0,05-ös p-érték is mutatja, hogy ebben az esetben szignifikáns az eltérés a két település mutatói között.

Eszerint kijelenthető, hogy világosabb életcéllal rendelkezik az, aki Gyergyószentmiklóson él, mint aki Nyíregyházán, egyúttal viszont az is, hogy semmilyen más életminőségi mutató értékével nem áll kapcsolatban az, hogy a megkérdezett a két lakóhely közül hol él.

\section{A NEM-VÁLTOZÓ ÉS AZ ÉLETMINŐSÉG KAPCSOLATA}

Elemzésünk következő lépésében, a lakhely és az életminőség kapcsolata után azt vizs gáltuk, hogy lehet-e szignifikáns eltérés az egyének válaszaiban, attól függően, hogy melyik nemet képviselik. Erre a 3. és 4. táblázatokban feltüntetett értékekkel, majd a hozzá füzött magyarázattal adunk választ.

Ami első ránézésre kiderül a táblázatból, az az, hogy szignifikáns összefüggés a nemváltozó és az első három életminőségi dimenzió között nem mutatható ki. Magyarán nem derült ki, hogy a férfiak lényegesen autonómabb, a környezetüket magasabb fokon uralóbb és személyes fejlődésben magasabb szinten lennének, mint a nök, vagy éppen fordítva.

Rápillantva az átlagértékekre, 57-től 60-ig terjedő számokat láthatunk a 84-es skálán, hasonlóan az előző kérdésblokkhoz. Az átlagos eltérés értéke szintén változatlan a korábbiakhoz képest, 9 és 12 között mozog. 
3. táblázat. A nem-változó kapcsolata az életminőség dimenzióival. (1. rész)

\begin{tabular}{|c|l|c|c|c|c|}
\hline $\begin{array}{c}\text { Életminőség- } \\
\text { dimenzió }\end{array}$ & \multicolumn{1}{|c|}{ Nem } & $\begin{array}{c}\text { Átlagérték a } \\
84-\text {-es skálán }\end{array}$ & $\begin{array}{c}\text { Átlagos } \\
\text { eltérés }\end{array}$ & F-érték & p-érték \\
\hline \multirow{2}{*}{ Autonómia } & Férfi & 58,25 & 9,63 & 0,6 & 0,43 \\
\cline { 2 - 6 } & Nö & 57,47 & 9,65 & & \\
\hline \multirow{2}{*}{$\begin{array}{c}\text { A környezet } \\
\text { uralása }\end{array}$} & Férfi & 59,6 & 10,49 & 2,47 & 0,11 \\
\cline { 2 - 6 } & Nö & 57,8 & 11,1 & & \\
\hline \multirow{2}{*}{$\begin{array}{c}\text { Személyes } \\
\text { fejlödés }\end{array}$} & Férfi & 58,57 & 10,2 & 0,06 & 0,79 \\
\cline { 2 - 6 } & Nó & 59,14 & 11,23 & & \\
\hline
\end{tabular}

A nemek közötti különbségek nem látszanak meg lényegesen az utolsó három életminőségi mutatóban sem. Ahogy az a 4. táblázatból is kiderül, a másokkal fenntartott pozitív kapcsolatok tekintetében a nők és a férfiak is 58-tól 61-ig terjedő eredményt értek el a 84es skálán, az átlagtól való eltérés mindkét nem esetében 10 körül marad, míg a p-érték nem mutat szignifikáns összefüggést. Mivel ugyanezek elmondhatók az életcélról és az önelfogadásról is, összegzésként kijelenthetjük, hogy a mintába bekerült férfiak és nők között nincs szignifikáns különbség az életminőségi mutatók tekintetében.

4. táblázat. A nem-változó kapcsolata az életminőség dimenzióival (2. rész)

\begin{tabular}{|c|l|c|c|c|c|}
\hline $\begin{array}{c}\text { Életminőség- } \\
\text { dimenzió }\end{array}$ & Nem & $\begin{array}{c}\text { Átlagérték } \\
\text { a 84-es skálán }\end{array}$ & $\begin{array}{c}\text { Átlagos } \\
\text { eltérés }\end{array}$ & F-érték & p-érték \\
\hline \multirow{2}{*}{$\begin{array}{l}\text { Pozitív kapcso- } \\
\text { latok másokkal }\end{array}$} & Férfi & 58,7 & 9,42 & 2,12 & 0,14 \\
\cline { 2 - 7 } & Nő & 60,55 & 10,59 & & \\
\hline \multirow{2}{*}{ Életcél } & Férfi & 57,17 & 9,33 & 0,31 & 0,57 \\
\cline { 2 - 7 } & Nő & 57,07 & 9,75 & & \\
\hline \multirow{2}{*}{ Önelfogadás } & Férfi & 59 & 10,54 & 2,04 & 0,15 \\
\cline { 2 - 7 } & Nő & 57,54 & 11,41 & & \\
\hline
\end{tabular}

\section{Az ÉLETKOR ÉS AZ ÉLETMINŐSÉG KAPCSOLATA}

Miután négy változó szempontjából megvizsgáltuk az életminőségi mutatók változatosságát, elérkeztünk a sorban utolsó demográfiai változóhoz, az életkorhoz. Itt három 
kategóriát hoztunk létre, ez egyébként felnőttkorú megkérdezettek táborán belül: 18-tól 35 éves korúakig, 36-tól 65 éves korúakig, illetve a 66 év fölöttiek. Előzetesen feltételezhető lenne, hogy fiatal és idős megkérdezettek életminőségi mutatói között számottevő eltérés van. Nézzük mit mutatnak a táblázatok ezen kérdések kapcsán. (5. és 6. táblázatok)

5. táblázat. Az életkor-kategóriák és az életminőség-dimenziók kapcsolata (1. rész)

\begin{tabular}{|c|l|c|c|c|c|}
\hline $\begin{array}{c}\text { Életminőség- } \\
\text { dimenzió }\end{array}$ & \multicolumn{1}{|c|}{ Életkor-csoport } & $\begin{array}{c}\text { Átlagérték a } \\
84-\text { es skálán }\end{array}$ & $\begin{array}{c}\text { Átlagos } \\
\text { eltérés }\end{array}$ & F-érték & p-érték \\
\hline \multirow{2}{*}{ Autonómia } & $18-35$ év & 59,49 & 9,75 & 1,59 & 0,2 \\
\cline { 2 - 6 } & $36-65$ év & 56,76 & 9,64 & & \\
\cline { 2 - 6 } & 66 év fölött & 57,23 & 6,26 & & \\
\hline \multirow{2}{*}{$\begin{array}{c}\text { A környezet } \\
\text { uralása }\end{array}$} & $18-35$ év & 59,4 & 10,74 & 0,04 & 0,95 \\
\cline { 2 - 6 } & $36-65$ év & 58,23 & 10,92 & & \\
\cline { 2 - 6 } & 66 év fölött & 66,47 & 11,66 & & \\
\hline \multirow{2}{*}{$\begin{array}{c}\text { Személyes } \\
\text { fejlödés }\end{array}$} & $18-35$ év & 57,74 & 10,37 & 2,11 & 0,12 \\
\cline { 2 - 6 } & $36-65$ év & 56,47 & 9,77 & & \\
\cline { 2 - 6 } & 66 év fölött & & & & \\
\hline
\end{tabular}

Az autonómia, a környezet fölötti uralom, illetve a személyes fejlödés esetében a legfiatalabb korosztály skálaátlaga magasabb az idősebbekénél. A legalacsonyabb értékekkel háromból két esetben a legidősebbek rendelkeznek, az átlagok közötti különbség azonban egyik életminőségi mutató esetében sem szignifikáns (lásd: 0,05-nél magasabb p-értékek).

Nincs ez másképp a másokkal fenntartott pozitív kapcsolatok, az életcél-tudatosság és az önelfogadás tekintetében sem. A 18-35 éves korosztály ezekben is magasabb skálaértékeket produkált, mint a nála idősebbek, viszont itt sincs szignifikáns összefüggés az életkor-kategóriához tartozás és az életminőségi mutatók között.

Vizsgálatunk eredménye tehát azt támasztja alá, hogy a megkérdezettek életminőségi mutatója nem függ attól, hogy hány évesek. 
6. táblázat. Az életkor-kategóriák és az életminőség-dimenziók kapcsolata (2. rész)

\begin{tabular}{|c|l|c|c|c|c|}
\hline $\begin{array}{c}\text { Életminőség-di- } \\
\text { menzió }\end{array}$ & \multicolumn{1}{|c|}{ Életkor-csoport } & $\begin{array}{c}\text { Átlagérték a } \\
84-\text {-es skálán }\end{array}$ & $\begin{array}{c}\text { Átlagos } \\
\text { eltérés }\end{array}$ & F-érték & p-érték \\
\hline \multirow{2}{*}{$\begin{array}{c}\text { Pozitív } \\
\text { kapcsolatok } \\
\text { másokkal }\end{array}$} & $18-35$ év & 60,83 & 9,46 & 0,14 & 0,87 \\
\cline { 2 - 6 } & $36-65$ év & 59,51 & 10,54 & & \\
\cline { 2 - 6 } & 66 év fölött & 58,11 & 9,77 & & \\
\hline \multirow{2}{*}{ Életcél } & $18-35$ év & 59,07 & 8,92 & 1,07 & 0,34 \\
\cline { 2 - 7 } & 36-65 év & 56,45 & 9,71 & & \\
\cline { 2 - 7 } & 66 év fölött & 62,52 & 9,42 & & \\
\hline \multirow{2}{*}{ Önelfogadás } & $18-35$ év & 57 & 11,35 & 1,24 & 0,28 \\
\cline { 2 - 7 } & $36-65$ év & 54,58 & 10,45 & & \\
\hline & 66 év fölött & & & & \\
\hline
\end{tabular}

\section{A CSALÁdi ÁLlAPOT ÉS AZ ÉLETMINŐSÉG KAPCSOLATA}

Válaszadóink között családi állapot szerint szerepeltek nőtlenek, illetve hajadonok, házasok, élettárssal élők, elváltak és özvegyek. A hat életminőségi dimenzióval való öszszevetés során azt vizsgáltuk, van-e szignifikáns különbség ezen családi állapot-csoportok mutatói között. (7. táblázat)

Az autonómia kérdésblokk esetében a 84-es skála legmagasabb átlagát a nőtlen, illetve hajadon egyének érték el. Különbségük a többi csoporthoz képest azonban nem szignifikáns, mint ahogy azt a túl nagy $(0,90$-es) p-érték és a túl kicsi $(0,25$-ös) F-érték is mutatja. A legnagyobb átlagos eltérést $(12,96)$ az élettárssal élők csoportjában fedeztük fel, a legkisebbet az özvegyeknél $(7,84)$.

A 7. táblázatban az is látható, hogy a környezet uralásában szintén a nőtlenek és haja donok bizonyultak leginkább sikeresnek a kérdőív alapján, és így volt ez a személyes fejlödés területén is. A személyes fejlődés esetében az is kiderült, hogy az említett családi állapot-csoport jóval magasabb átlagot ért el a skálán a többinél, ugyanakkor nem mondhatjuk el, hogy a családi állapot szignifikánsan meghatározná az egyének személyes fejlődését, mivel a p-érték, ha kevéssel is, de meghaladja a 0,05-öt. 
7. táblázat. A családi állapot-változó és az életminőség-dimenziók kapcsolata (1. rész)

\begin{tabular}{|c|c|c|c|c|c|}
\hline $\begin{array}{l}\text { Életminőség- } \\
\text { dimenzió }\end{array}$ & Nem & $\begin{array}{l}\text { Átlagérték a } \\
\text { 84-es skálán }\end{array}$ & $\begin{array}{l}\text { Átlagos } \\
\text { eltérés }\end{array}$ & F-érték & p-érték \\
\hline \multirow[t]{5}{*}{ Autonómia } & Nötlen, hajadon & 58,37 & 9,09 & 0,25 & 0,9 \\
\hline & Házas & 57,98 & 9,19 & & \\
\hline & Élettárssal él & 56,54 & 12,96 & & \\
\hline & Elvált & 56,59 & 11,44 & & \\
\hline & Özvegy & 55,93 & 7,84 & & \\
\hline \multirow{5}{*}{$\begin{array}{l}\text { A környezet } \\
\text { uralása }\end{array}$} & Nőtlen, hajadon & 59,67 & 8,63 & 0,82 & 0,5 \\
\hline & Házas & 58,81 & 11,3 & & \\
\hline & Élettárssal él & 57,68 & 11,32 & & \\
\hline & Elvált & 55 & 13,46 & & \\
\hline & Özvegy & 57,43 & 9,38 & & \\
\hline \multirow{5}{*}{$\begin{array}{l}\text { Személyes } \\
\text { fejlődés }\end{array}$} & Nőtlen, hajadon & 62,77 & 9,44 & 2,11 & 0,07 \\
\hline & Házas & 58,64 & 10,56 & & \\
\hline & Élettárssal él & 55,27 & 12,33 & & \\
\hline & Elvált & 55,68 & 13,67 & & \\
\hline & Özvegy & 57,25 & 7,81 & & \\
\hline
\end{tabular}

A nőtlenek és hajadonok a maradék három mutatóban is verik a mezőnyt, ahogyan azt a 8. táblázat is szemlélteti. A skálán elért átlagértékük mind a másokkal fenntartott pozitív kapcsolatok, mind az önelfogadás esetében meghaladja a 60-at, ráadásul az átlagtól való eltérés is e csoport esetében a legkisebb, ami azt igazolja, hogy az életminőség tekintetében egy homogén csoportról van szó.

Fontos megjegyezni azonban itt is, hogy szignifikáns különbség nincs a különböző családi állapotú egyének pozitív kapcsolat-fenntartó képessége, életcél-tudatossága és önelfogadása között, ahogyan ezt a p-értékek is igazolják. 
8. táblázat. A családi állapot-változó és az életminőség-dimenziók kapcsolata (2. rész)

\begin{tabular}{|c|c|c|c|c|c|}
\hline $\begin{array}{l}\text { Életminőség- } \\
\text { dimenzió }\end{array}$ & $\mathrm{Nem}$ & $\begin{array}{l}\text { Átlagérték a } \\
\text { 84-es skálán }\end{array}$ & $\begin{array}{l}\text { Átlagos } \\
\text { eltérés }\end{array}$ & F-érték & p-érték \\
\hline \multirow{5}{*}{$\begin{array}{c}\text { Pozitív } \\
\text { kapcsolatok } \\
\text { másokkal }\end{array}$} & Nötlen, hajadon & 61,05 & 8,4 & 0,7 & 0,59 \\
\hline & Házas & 60,29 & 10,2 & & \\
\hline & Élettárssal él & 57,95 & 11,29 & & \\
\hline & Elvált & 57,59 & 13,65 & & \\
\hline & Özvegy & 57,12 & 8,92 & & \\
\hline \multirow[t]{5}{*}{ Életcél } & Nötlen, hajadon & 59,03 & 7,04 & 1,56 & 0,18 \\
\hline & Házas & 57,09 & 9,4 & & \\
\hline & Élettárssal él & 55,18 & 12,98 & & \\
\hline & Elvált & 54,36 & 13,02 & & \\
\hline & Özvegy & 57,06 & 7,53 & & \\
\hline \multirow[t]{5}{*}{ Önelfogadás } & Nötlen, hajadon & 60,87 & 10,2 & 0,63 & 0,63 \\
\hline & Házas & 57,88 & 10,82 & & \\
\hline & Élettárssal él & 56,09 & 12,57 & & \\
\hline & Elvált & 56,13 & 14,1 & & \\
\hline & Özvegy & 55,62 & 9,01 & & \\
\hline
\end{tabular}

\section{AZ ISKOLAI VÉGZETTSÉG ÉS AZ ÉLETMINŐSÉG KAPCSOLATA}

Gyergyószentmiklós és Nyíregyháza megkérdezettjeit a korábbi változók mellett iskolai végzettség szerint is csoportosítottuk. Így hat végzettségi csoportot kaptunk: 8 általános vagy alatta, szakmunkásképző, szakközépiskola, gimnázium, föiskola és egyetem. A kategorizálást segítette az, hogy Magyarország és Románia oktatási rendszerében ugyan úgy tagolják a végzettségi szinteket. A következő két táblázatban (9. és 10. táblázatok) ezen csoportok életminőségi mutatóit szemléltetjük. 
9. táblázat. Az iskolai végzettség-változó

és az életminőségi dimenziók kapcsolata (1. rész)

\begin{tabular}{|c|c|c|c|c|c|}
\hline $\begin{array}{l}\text { Életminőség- } \\
\text { dimenzió }\end{array}$ & Iskolai végzettség & $\begin{array}{l}\text { Átlagérték a } \\
\text { 84-es skálán }\end{array}$ & $\begin{array}{l}\text { Átlagos } \\
\text { eltérés }\end{array}$ & F-érték & p-érték \\
\hline \multirow[t]{6}{*}{ Autonómia } & 8 általános vagy alatta & 56 & 6,99 & 1,24 & 0,28 \\
\hline & Szakmunkásképző & 55,24 & 8,72 & & \\
\hline & Szakközépiskola & 55,62 & 12,37 & & \\
\hline & Gimnázium & 57,47 & 10,25 & & \\
\hline & Főiskola & 58,26 & 8,82 & & \\
\hline & Egyetem & 59,67 & 8,37 & & \\
\hline \multirow{6}{*}{$\begin{array}{l}\text { Környezet } \\
\text { uralása }\end{array}$} & 8 általános vagy alatta & 57,4 & 8,59 & 3,55 & 0 \\
\hline & Szakmunkásképző & 54 & 15,09 & & \\
\hline & Szakközépiskola & 55,32 & 13,03 & & \\
\hline & Gimnázium & 57,08 & 11,71 & & \\
\hline & Főiskola & 60,23 & 8,67 & & \\
\hline & Egyetem & 61,84 & 7,54 & & \\
\hline \multirow{6}{*}{$\begin{array}{l}\text { Személyes } \\
\text { fejlődés }\end{array}$} & 8 általános vagy alatta & 58,8 & 8,94 & 4,62 & 0 \\
\hline & Szakmunkásképző & 55,13 & 14,23 & & \\
\hline & Szakközépiskola & 56,4 & 12,24 & & \\
\hline & Gimnázium & 58,21 & 10,74 & & \\
\hline & Főiskola & 62,59 & 7,19 & & \\
\hline & Egyetem & 62,78 & 7,43 & & \\
\hline
\end{tabular}

Ahogyan azt a 9. és 10. táblázatokban is láthatjuk, az iskolai végzettséget vizsgálva egy olyan változóhoz értünk, amely majdnem mindegyik életminőségi mutatóval szignifikáns összefüggésben áll. A főiskolát vagy egyetemet végzettek átlagértékei mindegyik dimenzió skáláján meghaladják a többi kategória eredményeit. Ez a különbség az autonómia esetében még nem volt akkora, hogy szignifikánsnak bizonyuljon, a többi dimenziónál viszont igen.

Ez bővebben azt jelenti, hogy a vizsgálat rávilágított, a magasabb iskolát végzettek jobban uralják környezetüket, személyes fejlődésük elörehaladottabb, tisztább életcé- 
lokkal rendelkeznek, inkább képesek másokkal való pozitív kapcsolatok kialakítására és fenntartására, illetve az önelfogadásra, mint az alacsonyabban iskolázott társaik. Megfigyelhető, hogy a skálán elért átlagok tekintetében a legalacsonyabb és legmagasabb értékek között minimum 6, de akár 9 fölötti értékek is előfordulnak.

10. táblázat. Az iskolai végzettség-változó

és az életminőségi dimenziók kapcsolata (2. rész)

\begin{tabular}{|c|c|c|c|c|c|}
\hline $\begin{array}{l}\text { Életminőség- } \\
\text { dimenzió }\end{array}$ & Iskolai végzettség & $\begin{array}{l}\text { Átlagérték a } \\
\text { 84-es skálán }\end{array}$ & $\begin{array}{l}\text { Átlagos } \\
\text { eltérés }\end{array}$ & F-érték & p-érték \\
\hline \multirow{6}{*}{$\begin{array}{c}\text { Pozitív } \\
\text { kapcsolatok } \\
\text { másokkal }\end{array}$} & 8 általános vagy alatta & 55,1 & 7,3 & 7,42 & 0 \\
\hline & Szakmunkásképző & 52,2 & 11,96 & & \\
\hline & Szakközépiskola & 54,37 & 10,31 & & \\
\hline & Gimnázium & 54,37 & 10,54 & & \\
\hline & Főiskola & 58,51 & 7,66 & & \\
\hline & Egyetem & 61,93 & 6,18 & & \\
\hline \multirow[t]{6}{*}{ Életcél } & 8 általános vagy alatta & 56,41 & 7,3 & 7,42 & 0 \\
\hline & Szakmunkásképző & 52,42 & 11,96 & & \\
\hline & Szakközépiskola & 54,57 & 10,31 & & \\
\hline & Gimnázium & 54,36 & 10,54 & & \\
\hline & Főiskola & 58,63 & 7,66 & & \\
\hline & Egyetem & 61,5 & 6,18 & & \\
\hline \multirow[t]{6}{*}{ Önelfogadás } & 8 általános vagy alatta & 55,7 & 10,08 & 5,53 & 0 \\
\hline & Szakmunkásképző & 53,63 & 14,4 & & \\
\hline & Szakközépiskola & 53,27 & 11,28 & & \\
\hline & Gimnázium & 55,97 & 12,48 & & \\
\hline & Főiskola & 60,18 & 8,19 & & \\
\hline & Egyetem & 62,57 & 8,15 & & \\
\hline
\end{tabular}

Az iskolai végzettségről tehát elsőként mondható el, hogy jelentős összefüggésben áll az egyének életminőségével, mégpedig úgy, hogy a magasabb végzettségủek jobb eredménnyel rendelkeznek az életminőség számos mutatója terén. 


\section{A KARDiOlógIAI ÁLLAPOT ÉS AZ ÉLETMINŐSÉG KAPCSOLATA}

Elemzésünk hatodik lépésében egy pszichoszociális, illetve egészségügyi változót vizsgáltunk meg és vetettünk össze az életminőség dimenzióival. Ez nem más, mint a kardiológiai állapot. A 252 érvényes választ adó egyén esetében arra kérdeztünk rá, hogy érte-e élete során szívinfarktus. Ebben a tekintetben jó mutatókkal rendelkeznek a mintába bekerült gyergyószentmiklósi és nyíregyházi egyének, hiszen mindössze négyük válaszolta azt, hogy volt szívinfarktusa.

Az életminőségi dimenziókkal való összevetésből is kiderült, hogy nincs szignifikáns összefüggés a kardiológiai állapot és hat mutató között, tehát az a tényező, hogy az egyént érte-e valaha szívinfarktus, nem meghatározó az illető autonómia-érzete, környezet fölötti uralma, személyes fejlödése, másokkal fenntartott pozitív kapcsolatai, életcélja és önelfogadása szempontjából, valószínűleg a kis elemszám miatt.

\section{Összefoglalás}

Kutatásunkban Gyergyószentmiklós és Nyíregyháza városaiban készítettünk kérdőíves életminőségi felmérést. Kérdésblokkjainkat hat életminőségi dimenzió mentén építettük fel, az így kapott válaszokat pedig összevetettük a legfontosabb demográfiai és pszichoszociális változókkal. Ezen elemzés célja az volt, hogy kimutassuk, van-e szignifikáns összefüggés az egyének lakóhelye, neme, családi állapota, iskolai végzettsége, életkora és kardiológiai állapota, valamint az életminőség hat dimenziója között.

Az eredmények azt mutatják, hogy a hat változóból négy nem hat szignifikánsan egyik életminőségi dimenzióra sem. Kettő esetében viszont találtunk összefüggést, ezek az iskolai végzettség és a lakóhely.

Az iskolai végzettség változója szignifikáns összefüggésben áll a környezet fölötti uralommal, a személyes fejlődéssel, a másokkal kialakított pozitív kapcsolatokkal, az életcéllal, valamint az önelfogadással is. Egész pontosan a magasabb iskolai végzettséggel rendelkezők jóval magasabb életminőség átlagokkal rendelkeznek a vizsgált skálákon, mint az alacsonyabban iskolázott társaik. Hasonló összefüggést emellett egy esetben találtunk, mégpedig a lakóhely és az életcél között. Kiderült, a gyergyószentmiklósiak átlagban világosabb életcélokkal rendelkeznek, mint a nyíregyháziak, a kettejük közötti különbség pedig szignifikáns.

Konklúzióként tehát kijelenthetjük, hogy a mintába bekerült gyergyószentmiklósi és nyíregyházi egyének autonómiaérzetét sem az öt legfontosabb demográfiai változó, sem a pszichoszociális jellegü kardiológiai állapot nem befolyásolja számottevő módon. A környezet fölötti uralmukat, személyes fejlődésüket, életcéljukat, másokkal fenntartott pozitív kapcsolataikat és önmaguk elfogadását szignifikánsan meghatározza iskolai végzettségük, életcéljukat továbbá a lakóhelyük is. Vajon az eredmények valóban tükrözik a valóságot? És tényleg ilyen nagy befolyása lenne életminőségünkre az, hogy felsőfokú diplomával rendelkezünk? És ha igen, akkor miért van ez így? Mindennek a lehetséges magyarázata a Maslow (1954) féle piramissal függ össze, amelynek 
alapját képzik a fiziológiai szükségletek, majd a biztonságérzés és fizikai biztonság, a szeretet és valahová tartozás, a megbecsülés, míg a legmagasabb szinten az önmegvalósítás szükségletei állnak. Talán egy kissé naiv következtetés, de mindenképpen egy lehetséges magyarázat a feltett kérdésekre, a következö, Maslow-i elméleten alapuló feltevés: ha valaki felsőfokú végzettséggel rendelkezik, megfelelően el tud helyezkedni az érdeklődési területén, megfelelő kereslettel rendelkezik, kapcsolatai révén, melyeket tanulmányai vagy munkája során szerzett, több lehetőség tárul elé. Ha ezek segítségével megtalálhatja magának a boldogulás útját, akkor valószínü, hogy a pszichológiai életminősége is magasabb lesz. Anyagi biztonsága révén, a piramis alján lévő szinteket megfelelően ki tudja elégíteni és így koncentrálni tud az önmegvalósítás szükségletére, amelynek következtében életminősége is jónak bizonyulhat. A felnőtt lakosság végzettségével kapcsolatosan csak Nyíregyháza esetében van adatunk, a 2001-es népszámlálási statisztikák alapján. Ebből kiderül, hogy az illető évben Nyíregyháza 25 éves vagy idősebb lakosságának 18\%-a rendelkezett diplomával (Malakucziné, 2012).

\section{Felhaszálet irodalom}

1. Dr. Tringer László (2005): Korszerü emberkép-lelki egészség. In: Életminőség - holisztikus szemlélettel, Nádasdy Alapítvány, Budapest, 38-42 o.

2. INSSE (2011): Rezultate preliminare România pe județe, municipii și orașe, comună - http://www.recensamantromania.ro/rezultate-2/ (letöltés ideje:2013.05.05)

3. Kopp Mária, Kovács Mónika Erika dr. (szerk.) (2006): A magyar népesség életminösége az ezredfordulón, Semmelweis Kiadó, Budapest.

4. Malakucziné Póka Mária (2012): Nyíregyháza lakosságának föbb demográfiai jellemzöi, In: Fábián Gergely (szerk.): Életminőség Nyíregyházán 2008-2010, Acta Medicinae et Sociologica folyóirat különszáma, Nyíregyháza, 11-33

5. Maslow, Abraham (1954): Motivation and Personality NY: Harper, 1954.

6. Népszámlálási adatok, Szabolcs-Szatmár-Bereg megye, KSH, Budapest, 2011 - letöltés ideje: 2013.05.05 - http://www.ksh.hu/nepszamlalas/tablak_teruleti_15

7. Ryff, C. (1989). Happiness is everything, or is it? Explorations on the meaning of psychological well-being. Journal of Personality and Social Psychology, 57, 10691081.

8. Stauder Adrienne, Novák Márta (2001): Az életminöség-vizsgálatok általános szempontjai. In: (Szerk.) Újszászy László, Udvardy Miklós, Kupcsulik Péter: Életminőség és vizsgálata a gasztroenterológiában, Budapest, MGT, 45-58 o. 
